DOI 10.7251/SCMED1802105B UDC 616.379-008.64-06 COBISS.RS-ID 7837464

\title{
Complications of Diabetes Mellitus on Muscles and Joints of Lower Extremities
}

\section{ABSTRACT}

Introduction: Non-enzymatic protein glycosylation in diabetic patients leads to stiffening of collagen-containing tissues affecting joint mobility. Motor dysfunction in diabetic patients can be detected as muscle weakness or atrophy.

Objective: To determine the presence of muscles weakness and limited joint mobility at ankle (AJ), subtalar (SJ) and first metatarsophalangeal joint (I MTP) in diabetic patients and to determine impact of diabetes duration on those changes.

Patients and Methods: A cross-sectional study was conducted among 100 diabetic patients in "Primary Health Care Centre Banjaluka" in 2014. Function of ten foot and ankle muscles has been evaluated by manual muscle testing. Muscle strength was scored by semiquantitative grading system used in the Michigan Diabetic Neuropathy Score. Range of motion (ROM) at the AJ, SJ and I MTP was measured with goniometer.

Results: The average patients age was $61.91 \pm 10.74$ and diabetes duration $12.25 \pm 8.60$ years. The average strength of foot and ankle muscles expressed by muscle score was $11.56 \pm 5.08$. The average $\mathrm{ROM}$ at $\mathrm{AJ}\left(47.85^{\circ}\right)$ was significantly decreased compared to the reference value that is $65^{\circ}(t=-15.378, P=000)$. The average ROM at $\mathrm{SJ}\left(35.10^{\circ}\right)$ was significantly decreased compared to the reference value that is $50^{\circ}(\mathrm{t}=-15.378, \mathrm{P}=000)$. The average ROM at the I MTP $\left(72.70^{\circ}\right)$ was significantly decreased compared to the reference value that is $120^{\circ}(t=-15.378$, $\mathrm{P}=, 000)$.

Conclusion: Patients with diabetes have decreased foot and ankle muscle strength, and the average values of the range of motion at AJ, SJ and I MTP, but the duration of the diabetes does not correlate significantly with those changes.

Key words: diabetes, muscle strength, range of motion

(Scr Med 2018:49:105-111)

Snježana Novaković

Bursać,

Slavica Jandrićć,

Goran Talic ${ }^{1,2}$, Gordana Ljubojević ${ }^{x}$

${ }^{1}$ Institute for physical medicine and rehabilitation „Dr Miroslav Zotovic““ ${ }^{2}$ Faculty of Medicine, University of Banja Luka, Banja Luka, Republic of Srpska, Bosnia and Herzegovina

Corresponding author: Snježana Novaković Bursać e-mail:

snjezana.nb@ms.zotovicbl.org
Manuscript received: September $17^{\text {th }}, 2018$ Manuscript accepted: August $6^{\text {th }}, 2018$ 


\section{Introduction}

Diabetes mellitus (DM), or diabetes is the global epidemic of the $21^{\text {st }}$ century and it is now the fourth leading cause of death in most developed countries. ${ }^{1}$ Diabetes complications in the lower extremities are a major cause of morbidity, disability, emotional and physical suffering in people with $\mathrm{DM}^{2}$ generating at the same time huge economic costs for patients, their families and the entire society. ${ }^{3}$ Non-enzymatic glycosylation of the protein caused by long standing hyperglycemic state during longer DM duration leads to stiffening of collagen containing tissues, 45,6 which reflects joint structure decreasing elasticity of cartilage, ligaments, and joint capsule. ${ }^{5-7}$ A key factor of the tissue damage in patients with DM is gradually and excessive accumulation of advanced glycation end products (AGEs) that produce abnormal covalent cross-links within collagen fibers and other proteins. The most extensive accumulation of AGEs occurs in tissues with low turnover such as cartilage, bone and tendons. Once formed, AGEs can be decomposed only when the protein they are incorporated into is degraded. ${ }^{8}$

Limited joint mobility (LJM) at ankle joint (AJ), subtalar joint (SJ) and first metatarsophalangeal joint (MTP) results in high focal plantar pressures with increased ulceration risk in patients with neuropathy. ${ }^{4} \mathrm{LJM}$ is often overlooked because it causes small disablement and is thought to have less significant clinical consequences. Determination of the foot and ankle joint mobility is a simple and rather exact test to identify diabetic patients with an at-risk foot and, might be useful as a screening tool in diabetic patients to identify those with an at-risk foot because of its price and simplicity. ${ }^{6,9}$

Motor dysfunction in patients with DM can be detected as muscle weakness as well as atrophy of muscular tissue. It is usually found distally in the extremities, primarily in the lower extremities and is believed to be caused by diabetes neuropathy (DN). ${ }^{10}$ Muscle atrophy is closely related to severity of DN. Since DN shows a centripetal pattern of progression, quantification of the more distally situated foot muscles could possibly serve as an early marker for motor dysfunction in $\mathrm{DN} .{ }^{11}$ Although muscular weakness has an important role in losing independence and impairing the quality of life, it represents neglected complication of long-term DM. ${ }^{12}$ Muscle strength reduction is most commonly associated with the presence of $\mathrm{DN},{ }^{10,13,14}$ but studies have shown the existence of muscular weakness in patients without neuropathy, suggesting the existence of other mechanisms that affect it. ${ }^{7}$ The association among ROM, muscle strength and function loss can lead to altered foot rollover during gait, as their integrity is needed to enable proper load absorption. ${ }^{5}$ Elevated plantar pressure coupled with a longer period of time spent in support phase in DN patients contributes to the susceptibility for skin damage through a prolonged mechanical load on tissue leading to skin breakdown and ulceration. ${ }^{15}$

Keeping in mind serious consequences that complications of DM in the lower extremities make on a personal and social level, inevitably raises the question what can be done to reduce their rate and severity. The implementation of strategies that include education, multidisciplinary treatment of foot ulcers and close monitoring, can reduce the rate of diabetic amputations between $49 \%$ and $85 \% .4,16-18$ Proper metabolic control of both types of DM may delay the onset and progression of diabetic complications. ${ }^{19}$

\section{Objective}

To determine the presence of the foot and ankle muscles weakness and limited joint mobility at the AJ, SJ and first MTP in people with diabetes and to determine the impact of the diabetes duration on those changes.

\section{Patients and Methods}

A cross-sectional study was conducted among 100 diabetic patients (both type DM) who are registered with family physicians in the "Primary Healthcare Centre Banja Luka" during 2014. The sample was formed in a way that the patients who approached family doctor for a prescription for insulin or oral antidiabetic drugs in 10 family medicine ambulances were over the time successively asked to enter the study. The survey included: the review of medical records, history-taking, measurement and testing. The study was approved by the local ethics committee and informed consent was obtained from patients.

Medical records were source of personal data, data on DM - type, therapy and HbA1c value not older than 6 months. History-taking data were entered in the anamnestic list, and include information about duration and treatment of DM. ${ }^{20,21}$ The clinical examinations of muscles and joints were performed routinely by the same examiner.

Muscle function of the foot and ankle muscles has been evaluated by manual muscle testing (MMT) on the dominant leg. MMT means assessing ability of the muscle to produce active movement against the examiner's resistance. Muscle strength (i.e., weakness) was scored using a semiquantitative grading system that was based on the scoring system as used in the Michigan Diabetic Neuropathy Score.5,22,23 Muscle weakness was scored as o for normal muscle strength, 1 for mild, 2 for severe weakness, and 3 for complete loss of strength. 
A muscle score (MS) was, therefore, obtained for each set of muscles examined. Higher values for this score represented increased muscle weakness. ${ }^{22,24}$ In the positions described for manually clinical assessment ${ }^{25}$ the function of the following muscles was evaluated: triceps surae, tibialis anterior, interosseus, lumbrical, flexor hallucis brevis, extensor digitorum brevis, extensor digitorum longus, flexor digitorum brevis, extesnosor hallucis longus and extensor hallucis brevis. ${ }^{5}$

Joint mobility at the AJ, SJ and first MTP was measured with a goniometer on the dominant lower limb. At the AJ range of motion (ROM) was measured with the patient supine and goniometer set with immobile prong in line with calf, mobile prong in line with external edge of the foot and center of goniometer above the joint center. The maximum range of active talar flexion and extension was measured and the sum of the values was recorded as ROM at the AJ. At the SJ ROM was measured with the patient pronate; a vertical line was marked on the patient's skin from heel to midcalf; goniometer set with immobile prong in line with the line on the calf, mobile prong in line with the line on the heel and center of goniometer above the joint center; the maximum range of calcaneal active inversion and eversion were measured with a goniometer and the sum of the values was recorded as ROM at the SJ. At the first MTP range of active extension to plantar flexion was measured with the patient in the supine position; horizontal line was drawn from the first toe to the heel in line with medial edge of the foot; goniometer center set above the joint center, immobile prong in line with proximal part of drawn line and mobile prong in line with the distal part of the line; the sum of maximal extension and flexion was recorded as ROM at first MTP joint. ${ }^{26,27}$ As a reference value of ROM is considered a sum of the minimal normal values of the movement amplitude cited in relevant literature. ${ }^{28}$

The statistical analyses were done using the software package "IBM SPSS Statistics". To test the statistical significance between variables the ANOVA and the Student's t test were applied. The cut off for the results significance was $\mathrm{p}<0.05$.

\section{Results}

There were more women (53\%) than men (47\%) in the

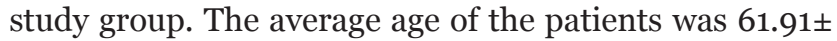
10.74 years. The majority of patients ( $94 \%$ ) had DM type 2 while type $1 \mathrm{DM}$ had $6 \%$ of them. The average duration of diabetes was $12.25 \pm 8.60$ years. In the study group $86 \%$ of patients had HbA1C test result not older than 6 months, while $14 \%$ of patients did not have it. The average value of $\mathrm{HbA1C}$ in the study group was $7.85 \% \pm 1.73$. The even number of patients was treated with insulin and oral antidiabetic drugs ( $46 \%$ each), and combined oral and parenteral therapy had $8 \%$ of the patients. The average muscle strength of the foot and ankle muscles expressed by MS was $11.56 \pm 5.08$. The duration of the DM and muscle strength were not significantly correlated ( $\mathrm{r}$ $=1.41, \mathrm{p}=.160$ ).

Relation between the muscle strength and duration of the DM is shown in Chart 1. The muscle strength was below the average value in patients with a duration of DM more than 11 years, whereas the muscle strength was above average or closely average value in patients with a duration of DM below ten years. With the increased duration of the DM muscle strength tends to decrease, but this difference was not statistically significant $(\mathrm{F}=0.583, \mathrm{p}=677)$.

\section{Chart 1. Correlation of diabetes duration and muscle strength expressed by muscle score $(n=100)$}

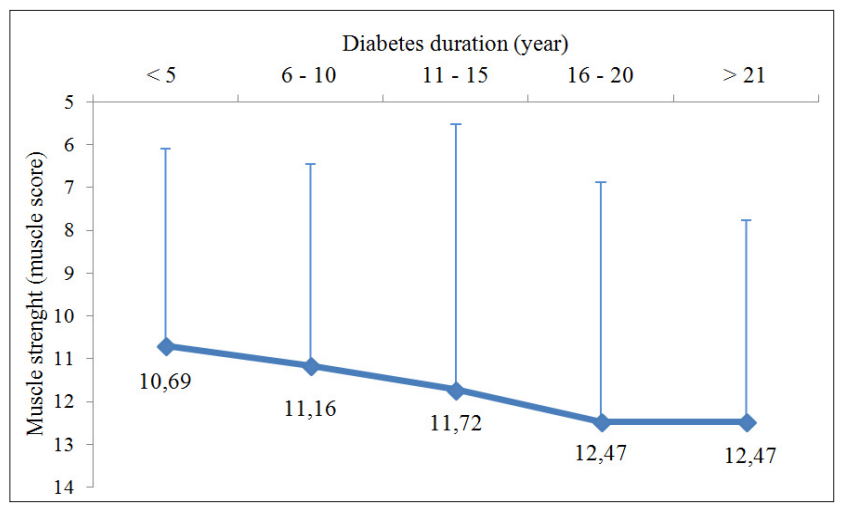

Study results of the ROM at AJ, SJ and I MTP in patients with DM are shown in Table 1.

Table 1. Results of measurement of the active mobility at ankle joint, subtalar joint and first metatarsophalangeal joint in diabetic patients $(n=100)$

\begin{tabular}{lccc} 
& $\begin{array}{c}\text { Average } \\
\text { value of the } \\
\text { ROM }\end{array}$ & $\begin{array}{c}\text { Reference } \\
\text { value of the } \\
\text { ROM }^{*}\end{array}$ & $\mathrm{p}$ \\
\hline AJ mobility $\left(^{\circ}\right)$ & $47.85 \pm 11.2$ & 70 & .000 \\
SJ mobility $\left(^{\circ}\right)$ & $35.10 \pm 8.7$ & 50 & .000 \\
I MTP mobility $\left(^{\circ}\right)$ & $72.20 \pm 21.1$ & 115 & .000 \\
\hline
\end{tabular}

AT - ankle joint, SJ - subtalar joint, I MTP - first metatarsophalangeal joint;

The average ROM at AJ was $47.85^{\circ}$ and was statistically significantly decreased compared to the reference value that is $65^{\circ}(\mathrm{t}=-15.378, \mathrm{P}=000)$. The average ROM at SJ measured in examined patients was $35.10^{\circ}$ and it was 
statistically significantly decreased compared to the reference value that is $50^{\circ}(\mathrm{t}=-15.378, \mathrm{P}=000)$. The average ROM at the first MTP joint in the study group was $72.70^{\circ}$ and it was statistically significantly decreased compared to the reference value that is $120^{\circ}(\mathrm{t}=-15.378$, $\mathrm{P}=000$ ). The duration of diabetes has not influenced significantly the mobility at the $\mathrm{AJ}(\mathrm{F}=0.8008, \mathrm{p}=0.5276)$, the SJ $(\mathrm{F}=0.8965, \mathrm{p}=0.4693)$ and the first MTP joint $(\mathrm{F}=0.6942, \mathrm{p}=0.5977)$ as shown in Chart 2.

Chart 2. The influence of the diabetes duration on the range of motion at ankle joint, subtalar joint and first metatarsophalangeal joint in diabetic patients $(n=100)$

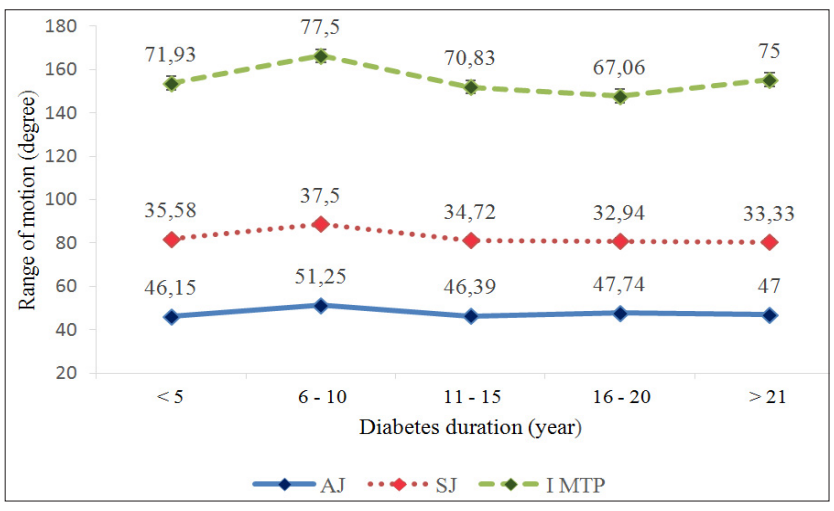

$A T$ - ankle joint, SJ - subtalar joint, I MTP - first metatarsophalangeal joint.

\section{Discussion}

Muscle function of the foot and ankle muscles in this study has been evaluated in ten muscles applying the scoring system as used in the Michigan Diabetic Neuropathy Score. Mean MS of evaluated muscles was 11,56 and represents mild muscle weakness in the study group. Only $13 \%$ of patients had preserved muscle strength, $23 \%$ of patients had severe muscle weakness, none of them had complete loss of strength, while the most of patients (64\%) had mild muscle weakness. Data from this study are consistent with the results of research that has been done by Andersen10 ${ }^{13}$, Andreassen ${ }^{14}$, Giacomozzi ${ }^{7}$ and $\mathrm{Camargo}^{29}$, that have confirmed the existence of a decrease in muscle strength in people with DM, especially in the region of ankle and knee. Van Shie stated that more than $40 \%$ of patients with DM had a decreased muscle strength. ${ }^{22}$ Muscle quality (power per muscle mass unit) is lower in patients with DM, particularly with the longer duration and poorer control of the disease. Decrease in muscle strength has been found even in people who had impaired glucose tolerance..$^{10}$ Ijzerman led the study on the impact of DM and DN on muscle strength, mobility and quality of life. The results of the study shown that $\mathrm{DM}$ affects the reduction of muscle strength by $30-50 \%$ in the upper and lower extremities, and that loss of strength and decreased mobility reinforce each other by reducing individual, and in particular associated quality of life of patients with diabetes. ${ }^{30}$ Loss of muscle strength is an expected consequence of motor nerves damage as a part of neuropathy, while DM affects strength loss by some other factors such as the abnormality of intrinsic muscle, damage in capillary flow, peripheral arterial disease and damage to myofascial structure due to hyperglycemia. ${ }^{12,29}$ Balducci has found that the loss of muscle strength is related to the appearance of $\mathrm{DN}$, but also to the other microvascular and macrovascular complications, and the loss of muscle strength in patients with DM is affected by poor transport of blood after the contraction that occurs as a result of damage to the autonomic nerve fibers. ${ }^{12}$ Greenman has proven that diabetic patients had diminished oxygen supply to the muscle cells and decreased muscle energy reserves as a result of changes in the microcirculation. He has also found that muscles atrophy in the diabetic foot already existed during the subclinical stage of $\mathrm{DN}$, even before the development of clinical signs of disease. ${ }^{31}$ Sawacha demonstrated the presence of changes in the electrical activity of the muscles in the patient with DM which could not be correlated with the presence of DN. ${ }^{32}$ Identified early changes in the muscles of patients with $\mathrm{DM}$, but also the all other changes of musculoskeletal system, indicate the need for planning and implementing prevention and rehabilitation programs aimed at reducing all consequences of DM, not only DN. ${ }^{22,33}$

Studies on ROM at AJ, SJ and first MTP joint shown that those three joints were reliable mobility measurement locations. ${ }^{34}$ The average values of the ROM at AJ, SJ and first MTP joint in the study group were significantly lower than the reference value of ROM in these joints. Data obtained by conducted study are in compliance with data from the other studies. ${ }^{35-38}$ Golsdmith found that the LJM can be found in up to $30 \%$ of children with DM type 1 , and in up to $45 \%$ of adult patients with DM type $2 .{ }^{37}$ Somai states that between $30 \%$ and $40 \%$ of the patients with DM have LJM. ${ }^{39}$ Giacomozzi confirmed the existence of LJM in all directions at the AJ and SJ in patients with DM explaining it by changes in the structure that reduce the elasticity of the cartilage and joint capsules. ${ }^{7}$ Muelle have found a significant difference in the ROM at AJ and SJ in patients with diabetic ulcer compared with the control group without DM..$^{35}$ Rao has confirmed the existence of limited passive dorsiflexion and elasticity at the AJ which it is considered as key factor of the increased plantar pressure in patients with DM. ${ }^{40}$

This study did not confirm the influence of the duration of DM to the RAM at AJ, SJ and first MTP joint. The development of the LJM is complex and multifactorial, 
caused by the changes in anatomical structures involving the skin, subcutaneous tissue, muscle, joint capsules, tendons, ligaments and the bone components.35,39 Accumulation of AGEs due to hyperglycemia is one of the most important factors of the tissue damage in patients with DM. ${ }^{8,41}$ The main mechanical effect of AGEs is loss of viscoelasticity of the tissue that occurs due to damaged fiber sliding at the level of extracellular matrix which has potentially important implications for the tissue damage accumulation, mechanically regulated cellular signals and the matrix remodeling. ${ }^{42}$

The tissues damage in diabetic patients causes the alterations in the segmental mobility and affects foot rollover process..$^{5,6,43}$ The reduced ankle ROM may interfere in the foot adaptation to changes in foot-floor interaction. Foot rollover process is dependent on the proper mobility of ankle and foot joint to ensure adequate contact of the plantar regions in a progressive temporal order from the heel to the metatarsal heads and hallux during the load phase. The alterations in the foot rollover process will lead to an alterations of loads distribution over the plantar surface and predispose it for ulcer development. ${ }^{44}$ Prolonged hyperglycemia causes other structural changes such as the skin thickening, atrophy and impaired muscle activation affecting additionally the physiological gait mechanism. ${ }^{45}$

The goals of physiotherapy in patients with DM are prevention of complications, decrease the effects of immobilization, maintenance of functional capacity and minimizing the presence of the complication. ${ }^{46}$ Physiotherapy moderately changes the rollover process of the foot toward the physiological movement in patients with $\mathrm{DM}$ and at the same time improves the distribution of a dynamic pressure, torque of the ankle extensors and functionality of the foot and ankle muscles. Specific gait and balance training in combination with functionally oriented strengthening may improve gait and balance, muscle strength, and increase the mobility of joints in patients with DM.45,47,48 Physical therapy may improve the mobility of ankle and foot joints and thus be useful in the prevention of diabetic ulcer that need to be proven by further research.

\section{Conclusion}

Patients with diabetes have decreased foot and ankle muscle strength, and the duration of the diabetes does not correlate significantly to the muscular strength. In patients with DM, the average values of the range of motion at ankle, subtalar joint and first metatarsophalangeal joint are significantly lower compared to the reference value while the duration of diabetes does not correlate significantly with the mobility of the foot and ankle joints.

\section{References}

1. International Diabetes Federation. IDF Diabetes, 7 ed. Brussels, Belgium: International Diabetes Federation, 2015. http://www.diabetesatlas.org

2. International Diabetes Federation. International Working Group on the Diabetic foot. Diabetes and Foot Care: Time to Act 2005, Brussels, Belgium, 2005.

3. American Diabetes Association. Preventive foot care in diabetes. Diabetes Care 2004; 27(1):63-4.

4. Frykberg RG, Zgonis T, Armstrong DG, Driver VR, Giurini JM, Kravitz SR, et al. Diabetic foot disorders. A clinical practice guideline (2006 revision). J Foot Ankle Surg 2006;45(5):1-66.

5. Sartor CD, Watari R, Pássaro AC, Picon AP, Hasue RH, Sacco ICN. Effects of a combined strengthening, stretching and functional training program versus usual-care on gait biomechanics and foot function for diabetic neuropathy: a randomized controlled trial. BMC Musculoskelet Disord 2012;13:36.

6. Zimny S, Schatz H, Pfohl M. The role of limited joint mobility in diabetic patients with an at-risk foot. Diabetes Care 2004;27:942-46.

7. Giacomozzi C, D’Ambrogi E, Cesinaro S, Macellari V, Uccioli L.Muscle performance and ankle joint mobility in long-term patients with diabetes. BMC Musculoskelet Disord 2008;9:99. doi: 10.1186/1471-2474-9-99.

8. Abate M, Schiavone C, Salini V, Andia I. Management of limited joint mobility in diabetic patients. Diabetes Metab Syndr Obes 2013; 6:197-207.

9. Fernando DJ, Masson EA, Veves A, Boulton AJ. Relationship of limited joint mobility to abnormal foot pressures and diabetic foot ulceration. Diabetes Care 1991;14(1):8-11.

10. Andersen H. Motor dysfunction in diabetes. Diabetes Metab Res Rev 2012;28 Suppl 1:89-92.

11. Andersen H, Gjerstad MD, Jakobsen J. Atrophy of foot muscles: a measure of diabetic neuropathy. Diabetes Care 2004; 27(10):2382-5.

12. Balducci S, Sacchetti M, Orlando G, Salvi L, Pugliese L, Salerno G, et al. Correlates of muscle strength in diabetes: The study on the assessment of determinants of muscle and bone strength abnormalities in diabetes (SAMBA). Nutr Metab Cardiovasc Dis 2014;24(1):18-26.

13. Andersen H, Nielsen S, Mogensen CE, Jakobsen J. Muscle strength in type 2 diabetes. Diabetes 2004;53(6):1543-8.

14. Andreassen CS, Jakobsen J, Andersen H. Muscle weakness: a progressive late complication in diabetic distal symmetric polyneuropathy. Diabetes 2006;55(3):806-12.

15. Fernando M, Crowther R, Lazzarini P, Sangla K, Cunningham M, Buttner $\mathrm{P}$, et al. Biomechanical characteristics of peripheral diabetic neuropathy: A systematic review and meta-analysis of findings from the gait cycle, muscle activity and dynamic barefoot plantar 
pressure. Clin Biomech 2013;28(8):831-45.

16. Bakker K, Apelqvist J, Schaper NC; International Working Group on Diabetic Foot Editorial Board. Practical guidelines on the management and prevention of the diabetic foot 2011. Diabetes Metab Res Rev 2012;28(1):225-31.

17. Ortegon MM, Redekop WK, Niessen LW. Cost-effectiveness of prevention and treatment of the diabetic foot: a Markov analysis. Diabetes Care 2004;27(4):901-7.

18. Diabetes UK. London: State of the nation (England): challenges for 2015 and beyond. Available from: https:// www.diabetes.org.uk/Documents /About\%20Us / What\%20we\%20say/State\%20of\%2othe\%2onation\%20 2014.pdf [Accessed 3 March 2015].

19. Brownlee M. The pathobiology of diabetic complications: a unifying mechanism. Diabetes 2005;54(6):1615-25.

20. Boyko EJ, Ahroni JH, Stensel V, Forsberg RC, Davignon DR, Smith DG; A prospective study of risk factors for diabetic foot ulcer. The Seattle Diabetic Foot Study. Diabetes Care 1999;22(7):1036-42.

21. Tapp RJ, Shaw JE, de Courten MP, Dunstan DW, Welborn TA, Zimmet PZ; AusDiab Study Group. Foot complications in type 2 diabetes: an Australian population-based study. Diabet Med 2003;20:105-13.

22. van Schie CHM, Vermigli C, Carrington AL, Boulton A. Muscle weakness and foot deformities in diabetes: relationship to neuropathy and foot ulceration in caucasian diabetic men. Diabetes Care 2004;27:1668-73.

23. Feldman EL, Stevens MJ, Thomas PK, Brown MB, Canal $\mathrm{N}$, Greene DA. A practical two-step quantitative clinical and electrophysiological assessment for the diagnosis and staging of diabetic neuropathy. Diabetes Care 1994;17(11):1281-9.

24. Bokan V. Muscle weakness and other late complications of diabetic polyneuropathy. Acta Clin Croat 2011;50(3):351-5.

25. Lacote M. Chevalier AM, Miranda A, Bleton JP, Stevenin P. Clinical evaluation of muscle function. Edinburgh, London, Melbourn and New York: Churchill Livingstone, 1987.

26. Jandrić S. Osnovi fizikalne medicine i rehabilitacije. Laktaši: Grafomarkt; 2009.

27. Stevanović M, Stevanović M. Merenje obima pokreta u zglobovima. Beograd: Zavod za rehabilitaciju „Dr Miroslav Zotović“; 1975.

28. Magee DJ. Lower Leg, Ankle, and Foot. in Orthopedic Physical Assessment, 4th edition. Philadelphia, Pa: W.B. Saunders; 2002.

29. Camargo MR, Barela JA, Nozabieli AJ, Mantovani AM, Martinelli AR, Fregonesi CE. Balance and ankle muscle strength predict spatiotemporal gait parameters in individuals with diabetic peripheral neuropathy. Diabetes Metab Syndr 2015;9(2):79-84.

30. IJzerman TH, Schaper NC, Melai T, Meijer K, Willems PJ, Savelberg HH. Lower extremity muscle strength is reduced in people with type 2 diabetes, with and without polyneuropathy, and is associated with impaired mobility and reduced quality of life. Diabetes Res Clin Pract 2012;95(3):345-51.

31. Greenman RL, Khaodhiar L, Lima C, Dinh T, Giurini JM, Veves A. Foot small muscle atrophy is present before the detection of clinical neuropathy. Diabetes Care 2005; 28(6):1425-30.

32. Sawacha Z, Spolaor F, Guarneri G, Contessa P, Carraro E, Venturin A, Avogaro A, Cobelli C. Abnormal muscle activation during gait in diabetes patients with and without neuropathy. Gait Posture 2012;35(1):101-5.

33. Yavuzer G, Yetkin I, Toruner FB, Koca N, Bolukbas N. Gait deviations of patients with diabetes mellitus: Looking beyond peripheral neuropathy. Eura Medicophys 2006; 42(2):127-33.

34. Wrobel JS, Najafi B. Diabetic Foot Biomechanics and Gait Dysfunction. J Diabetes Sci Technol 2010;4(4):833-45.

35. Muelle MJ, Diamond JE, Delitto A, Sinacore DR. Insensitivity, Limited Joint Mobility, and Plantar Ulcers in Patients with Diabetes Mellitus. Phys Ther 1989;69(6):4539.

36. MatsuiN, Shoji M, KitagawaT, TeradaS. Factors affecting the range of motion of the ankle and first metatarsophalangeal joints in patients undergoing hemodialysis who walk daily. J Phys Ther Sci 2016;28(5):1560-4.

37. Goldsmith JR, Lidtke RH, Shott S. The effects of range-of-motion therapy on the plantar pressures of patients with diabetes mellitus. J Am Podiatr Med Assoc 2002;92(9):483-90.

38. Turner DE, Helliwell PS, Burton AK, Woodburn J. The relationship between passive range of motion and range of motion during gait and plantar pressure measurements. Diabet Med 2007;24(11):1240-6.

39. Somai P. Limited Joint Mobility in Diabetes Mellitus: The Clinical Implications. Rheumatology Network 2011 March. Available from: http://www.rheumatologynetwork.com/ articles/limited-joint-mobility-diabetes-mellitus-clinicalimplications. [Accessed 22 Nov 2016]

40. Rao S, Saltzman C, Yack HJ. Ankle ROM and stiffness measured at rest and during gait in individuals with and without diabetic sensory neuropathy. Gait Posture 2006; 24(3):295-301.

41. Shi L, Rui YF, Li G, Wang C. Alterations of tendons in diabetes mellitus: what are the current findings? Int Orthop 2015;39(8):1465-73.

42. Li Y, Fessel G, Georgiadis M, Snedeker JG. Advanced glycation end-products diminish tendon collagen fiber sliding. Matrix Biol 2013;32(3-4):169-77.

43. Hajrasouliha AR, Tavakoli S, Esteki A, Nafisi S, NoorolahiMoghaddam H. Abnormal viscoelastic behaviour of passive ankle joint movement in diabetic patients: an early or a late complication? Diabetologia 2005;48(6):1225-8.

44. Sacco IC, Hamamoto AN, Gomes AA, Onodera AN, Hirata $\mathrm{RP}$, Hennig EM Role of ankle mobility in foot rollover during gait in individuals with diabetic neuropathy. Clin 
Biomech 2009;24(8):687-92.

45. Sartor CD, Hasue RH, Cacciari LP, Butugan MK, Watari R, Pássaro AC, et al. Effects of strengthening, stretching and functional training on foot function in patients with diabetic neuropathy: results of a randomized controlled trial. Musculoskelet Disord 2014;15:137. doi: 10.1186/14712474-15-137.

46. Nagawa MHB, Shawky AF, Basant H. Gait Analysis in
Patients with Diabetic Peripheral Neuropathy. Med J Cairo Univ 2010;78(2):827-34.

47. Allet L, Armand S, de Bie RA, Golay A, Monnin D, Aminian $\mathrm{K}$, et al. The gait and balance of patients with diabetes can be improved: a randomised controlled trial. Diabetologia 2010;53(3):458-66.

48. Wrobel JS, Najafi B. Diabetic Foot Biomechanics and Gait Dysfunction. J Diabetes Sci Technol 2010;4(4):833-45.

\section{Mišićnozglobne komplikacije šećerne bolesti na donjim ekstremitetima}

\section{SAŽETAK}

Uvod: Hiperglikemijski uslovljena glikozilacija proteina kod oboljelih od dijabetesa dovodi do povećanja rigidnosti svih kolagenskih tkiva što se odražava na pokretljivost zglobova. Motorna disfunkcija kod oboljelih od dijabetesa se prepoznaje kao gubitak mišićne snage ili kao atrofija mišića.

Cilj rada: Utvrditi prisustvo promjena mišićne snage mišića pokretača stopala i prstiju i obima pokreta u gornjem nožnom (GNZ), donjem nožnom (DNZ) i prvom metatarzofalangealnom (I MTP) zglobu kod oboljelih od dijabetesa i utvrditi uticaj trajanja dijabetesa na te promjene.

Ispitanici i metode: Istraživanje je provedeno kao studija presjeka među oboljelima od dijabetesa u „Domu zdravlja u Banjaluci“ 2014. godine. Uzorak je činilo 100 ispitanika. Mišićna snaga je procjenjivanja manuelnim mišićnim testom (MMT) na deset mišića uz primjenu semikvantitativnog bodovnog sistema iz Michigan Diabetic Neuropathy Score-a. Obim pokreta u GNZ, DNZ i I MTP zglobu je mjeren goniometrom.

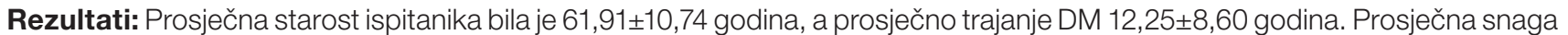
mišića pokretača stopala i prstiju izražena skorom mišićne slabosti je bila $11,56 \pm 5,08$. Prosječna vrijednost obima pokreta u GNZ $\left(47,85^{\circ}\right)$ je bila značajno manja $u$ odnosu na referentnu vrijednost $65^{\circ}(t=-15,378, p=, 000)$. Prosječna vrijednost obima pokreta u DNZ $\left(35,10^{\circ}\right)$ je bila značajno manja u odnosu na referentnu vrijednost $50^{\circ}(t=-15,378, p=, 000)$. Prosječna vrijednost obima pokreta u I MTP zglobu $\left(72,70^{\circ}\right)$ je bila značajno manja u odnosu na referentnu vrijednost $120^{\circ}(t=-15,378, p=, 000)$.

Zaključak: Oboljeli od dijabetesa imaju smanjenu mišićnu snagu mišića pokretača stopala i prstiju i smanjene amplitude pokreta u GNZ, DNZ i I MTP zglobu, ali trajanje dijabetesa ne utiče na te promjene.

Ključne riječi: dijabetes, snaga mišića, obim pokreta. 